\title{
HUBUNGAN KANDUNGAN BAHAN ORGANIK DENGAN TOTAL BAKTERI DI SEDIMEN MUARA SUNGAI WISO, JEPARA
}

\author{
The Relation of Organic Matter with Total Bacteria inWisoEstuarySediment, Jepara
}

\author{
Zulistiana Mufaidah, Supriharyono*),Max R. Muskananfola
}

Program Studi Manajemen Sumberdaya Perairan, Departemen Sumberdaya Akuatik

Fakultas Perikanan dan Ilmu Kelautan, Universitas Diponegoro

Jl. Prof. Soedarto, SH, Tembalang, Semarang, Jawa Tengah - 50275, Telp/Fax. +6224 7474698

Email : zulistianamufaidah77@gmail.com

\begin{abstract}
ABSTRAK
Muara merupakan salah satu ekosistem yang berada di pesisir, yang merupakan tempat terjadinya siklus dekomposisi unsur - unsur hara.Ketersediaan unsur hara didalam suatu perairan dapat menjadi indikator kesuburan perairan tersebut. Dalam hal ini, unsur hara yang dilihat adalah bahan organik sedimen yang terendap di perairan dasar Muara Sungai Wiso, Jepara. Zat hara tersebut sangat berperan penting terhadap kelangsungan hidup organisme didalamnya. Penelitian ini dilaksanakan pada bulan Maret - April 2016 dengan tujuan untuk mengetahui total bakteri, kandungan bahan organik dan hubungan antara total bakteri dan kandungan bahan organik total di sedimen Muara Sungai Wiso, Jepara. Metode penelitian yang digunakan dalam penelitian ini bersifat deskriptif eksplanatif.Pengambilan sampel pada Muara Sungai Wiso dilakukan pada tiga stasiun pengamatan. Stasiun I merupakan bagian hulu aliran air Muara Sungai Wiso. Stasiun II merupakan bagian tengah aliran air Muara Sungai Wiso. Stasiun III merupakan bagian aliran air Muara Sungai Wiso yang berbatasan langsung dengan pantai.Total bakteri di sedimen dasar Muara Sungai Wiso, Jepara berkisar antara 3,3 x $10^{5} \mathrm{cfu} / \mathrm{ml}$ hingga $1,2 \times 10^{7} \mathrm{cfu} / \mathrm{ml}$. Kandungan bahan organik di sedimen dasar muara Sungai Wiso, jepara berkisar antara $7,12 \%$ hingga $16,57 \%$. Bahan organik dengan total bakteri yang terdapat di sedimen dasar Muara Sungai Wiso Jepara tidak memiliki hubungan yang nyata $(\mathrm{P}>0,05)$.
\end{abstract}

Kata Kunci: Muara Sungai Wiso; Total Bakteri; Bahan Organik; Sedimen

\section{ABSTRACT}

Estuary is one of the important ecosystem located on the coast. Where of the decomposition cycle nutrient. The available of nutrients in the waters can be an indicator of water fertility. In this case, the element nutrient which is visible content of organic matter in sediment Wiso Estuary, Jepara. The nutrients are crucial to the survival of organism. The reseach was conducted on March - April 2016 in order to determine the total bacteria, the amount organic matter and relations between total bacteria and organic matter in the sediment Wiso estuary, Jepara. The method used in this research is descriptive explanation. Sampling was conducted at Wiso estuary at three observation stations. Station I is the upstream of Wiso estuarine stream. Station II is a center part of Wiso estuarine stream. Station III is the final part of Wiso estuarine stream which is directly adjacent to the beach. Total bacteria in bottom sediment Wiso estuarine, Jepara ranged between $3,3 \times 10^{5} \mathrm{cfu} / \mathrm{ml}$ up to $1,2 \times 10^{7} \mathrm{cfu} / \mathrm{ml}$. Content of Organic Matter in bottom sediment Wiso estuarine, Jepara ranged between 7,12 \% up to $16,57 \%$. Organic matter was not correlation with total bacteria $(\mathrm{P}>0,05)$ in bottom sediment Wiso estuarine Jepara.

Keywords: Wiso estuary; Total bacteria; Organic Matter; Sediment

\section{*) Penulis penanggungjawab}

\section{PENDAHULUAN}

Muara merupakan salah satu ekosistem penting yang berada di daerah pesisir. Muara juga termasuk tempat terjadinya siklus dekomposisi unsur-unsur hara dimana terjadi perombakan dari bahan organik menjadi anorganik yang sangat dibutuhkan algae untuk dapat memaksimalkan proses fotosintesis. Menurut Ghufran et al.(2007), estuari merupakan daerah yang kaya akan unsur hara dan jasad renik makanan alami, maka daerah ini merupakan daerah pengasuhan (nursery ground) dan daerah tempat mencari makan (feeding ground) bagi berbagai jenis biota laut seperti ikan, kerang dan udang. Daerah muara terdapat makanan yang melimpah bagi organisme air akan tetapi predator relatif sedikit. Hal ini dikarenakan muara sungai mempunyai produktifitas yang tinggi dan adanya penambahan zat-zat organik atau aliran nutrien yang berasal dari aliran sungai dan air laut untuk mendukung kehidupan fitoplankton. 
Bakteri sebagai dekomposer bahan-bahan organik sangat berperan aktif untuk menyediakan zat-zat hara di dasar perairan seperti bahan-bahan organik sedimen yang mengendap di dasar perairan. Oleh sebab itu, total bakteri di sebuah perairan dasar terutama dalam penyedia unsur hara dapat digunakan sebagai indikator kesuburan perairan. Menurut Kunarso dan Titiek (2012), hal ini dikarenakan komunitas bakteri merupakan komponen biotik dalam proses biogeochemical. Bakteri di lingkungan laut berperan sangat vital sebagai dekomposer yang menguraikan material organik menjadi komponen yang lebih sederhana sebagai unsur hara yang esensial.

Aktivitas bakteri dalam siklus unsur hara adalah suatu hal yang tidak bisa dipisahkan.Aktivitas bakteri tersebut tergantung pada ketersediaan karbon-karbon yang dioksidasi (Pollard dan Kogure, 1993 dalam Wijoyono, 2009).Bakteri merupakan pemeran utama dalam dekomposisi bahan organik serta siklus daur ulang unsur kimia seperti karbon dan nitrogen yang diperlukan bagi makhluk hidup (Wulandari, 2011).Bahan organik dan bakteri pengurai sebagai agen utama dalam dekomposisi pada daerah aliran sungai atau muara di sedimen keberadaannya belum begitu banyak diteliti.Metode pemantauan mutu perairan sungai atau muara yang digunakan selama ini menggunakan pendekatan pengukuran perubahan mutu air, yang diperoleh dari analisis contoh dari kolom air. Penggunaan parameter mutu air kurang tepat untuk perairan yang besifat dinamis seperti air sungai atau muara, dikarenakan air tersebut dapat berpindah-pindah setiap saat sesuai dengan arah arus dan kondisi pasang surut seperti yang terjadi di muara, sehingga tidak dapat mencerminkan dengan tepat mutu perairan pada waktu dan ruang tertentu. Kelemahan ini dapat diatasi dengan melakukan analisis sedimen yang relatif diam dan tidak bergerak. Dalam hal ini penggunaan sedimen sebagai acuan dianggap lebih tepat, oleh karena sedimen relatif diam tidak bergerak seperti air sungai, sehingga lebih representatif dan mewakili keadaan lokasi dimana sedimen tersebut diperoleh, yang dimaksud dengan sedimen adalah bahan atau materi yang terendap di dasar perairan atau bahan yang diendapkan oleh air.

Limbah yang dibuang langsung ke perairan Muara Sungai Wiso, Jepara seperti limbah rumah tangga, limbah pasar, limbah bahan bakar kapal yang dibuang ke badan sungai dan limbah TPI Ujung Batu diperkirakan telah menyebabkan peningkatan kandungan bahan organik diperairan Muara Sungai Wiso, Jepara. Kandungan bahan organik pada sedimen menunjukkan banyaknya bahan organik hasil dekomposisi jasad dari organisme yang telah mati, serasah (dedaunan) maupun bahan-bahan organik yang terbawa oleh arus air yang kemudian mengendap kedasar perairan.Penumpukan bahan organik di dasar perairan atau sedimen apabila terlalu tinggi dapat mengakibatkan adanya pencemaran lingkungan dasar perairan. Maka dari itu sangat dianjurkan untuk mencari informasi mengenai kandungan bahan organik serta total bakteri yang berada di sedimen, dan mencari informasi pengaruh kualitas parameter lingkungan pendukung yang sangat mempengaruhi kualitas sedimen dan juga kehidupan organisme didalamnya.

Tujuan penelitian ini adalah untuk mengetahui kandungan bahan organik disedimen Muara sungai Wiso Jepara,total bakteri di sedimen Muara Sungai Wiso Jepara, dan hubungan antara kandungan bahan organik dengan total bakteri di sedimen Muara Sungai Wiso, Jepara.

\section{MATERI DAN METODE PENELITIAN \\ Materi Penelitian}

Peralatan yang digunakan dalam penelitian ini meliputi alat pengambilan sampel, alat uji bakteri, alat uji bahan organik dan alat ukur parameter fisika kimia. Alat yang digunakan untuk pengambilan sampel sedimen yaitu sediment grabjenis Van Veen Grab dan cetokan. GPS (Global Positioning System) untuk menentukan titik lokasi pengambilan sampel. Bahan yang digunakan selama penelitian ini antara lain adalah sampel berupa substrat/ sedimen basah pada lokasi penelitian dan bahan-bahan uji bakteri meliputi: Aquades, Alkohol 70\%, Alkohol $96 \%$, Larutan air laut fisiologis Trisalt $\left(\mathrm{NaCl}, \mathrm{MgSO}_{4}\right.$, dan KCL), $\mathrm{Na}_{2} \mathrm{HPO}_{4},\left(\mathrm{NH}_{4}\right)_{2} \mathrm{HPO}_{4}, \mathrm{MgSO}_{4}$ $7 \mathrm{H}_{2} \mathrm{O}, \mathrm{MgCl}_{2}, \mathrm{FeCl}_{3} 6 \mathrm{H}_{2} \mathrm{O}, \mathrm{CaCl}_{2} 2 \mathrm{H}_{2} \mathrm{O}$, Agar- agar, Pepton casein, Yeast extract, Ekstrak tanah.

\section{Metode Penelitian}

Metode yang digunakan dalam penelitian ini adalah metode deskriptif eksplanatif yaitu mendeskripsikan atau menggambarkan objek-objek yang diteliti dan menjelaskan kedudukan masing-masing variabel yang diteliti. Menurut Sujarweni (2014), tingkat eksplanasi bermaksud menjelaskan kedudukan variabel-variabel yang diteliti serta hubungan antara satu variabel dengan variabel yang lain. Penelitian Deskriptif dilakukan untuk mengetahui nilai masing-masing variabel, baik satu variabel atau lebih sifatnya independen tanpa membuat hubungan maupun perbandingan dengan variabel lain. Variabel tersebut dapat menggambarkan secara sistematik dan akurat mengenai populasi atau mengenai bidang tertentu.Langkah-langkah kegiatan tersebut adalah sebagaimana uraian berikut:

\section{Penentuan Lokasi Sampling}

Penentuan lokasi pengambilan sampel dengan cara melakukan observasi di sekitar aliran Muara Sungai Wiso yang bertujuan untuk mencari lokasi sebagai obyek pengambilan sampel. Pengambilan sampel pada Muara Sungai Wiso dilakukan pada tiga stasiun pengamatan. Stasiun satu merupakan bagian hulu aliran air Muara Sungai Wiso. Stasiun dua merupakan bagian tengah aliran air Mura Sungai Wiso. Stasiun tiga merupakan bagian akhir aliran air Muara Sungai Wiso yang sudah berbatasan langsung dengan laut. Stasiun satu ke stasiun dua berjarak $950 \mathrm{~m}$ kemudian jarak antara stasiun dua dengan stasiun tiga adalah $700 \mathrm{~m}$.

\footnotetext{
${ }^{\circ}$ Copyright by Management of Aquatic Resources (MAQUARES)
} 
Teknik Pengambilan Sampel

Teknik pengambilan sampel yang digunakan adalah metode purposive sampling yaitu sampel diambil berdasarkan keperluan penelitian.Artinya setiap individu atau unit yang diambil dari populasi dipilih berdasarkan pertimbangan penulis.Pengambilan sampel sedimen untuk keperluan analisis parameter fisika kimia diambil menggunakan Van Veen Grab.Pengambilan sampel dilakukan pada tiga titik stasiun yang mana setiap stasiun diambil tiga titik yaitu bagian tepi utara, tengah, tepi selatan badan sungai kemudian ketiga sampel dikomposit. Selanjutnya sampel komposit di analisis dilaboratorium untuk mengukur total bakteri dan bahan organik sedimen. Perairan muara merupakan perairan yang sangat dipengaruhi oleh kondisi pasang dan surut, oleh sebab itu pengambilan sampel dilakukan ketika air surut dan air pasang, hal ini bertujuan untuk mengetahui ada atau tidaknya perbedaan hasil pengambilan ketika air surut dan air pasang. Selain itu pengukuran yang dilakukan secara in situ adalah pengukuran kecerahan, kedalaman, kecepatan arus, suhu, pH, dan salinitas.

\section{Analisis Total Bakteri}

Pengukuran total bakteri sedimen dilakukan sesuai dengan metode yang digunakan Balai Besar Pengembangan Budidaya Air Payau (BBPBAP) Jepara yaitu berdasarkan SNI-01-2339-1991 penentuan angka lempeng total, langkah-langkahnya yaitu sebagai berikut:Bakteri yang dihitung merupakan total bakteri yang terdapat di sedimen Muara Sungai Wiso,Jepara.Penentuan kandungan bakteri tanah dilakukan dengan terlebih dahulu menyiapkanlarutan trisalt untuk pengenceran dan ekstraksi tanah sebagai bahan campuran dalam pembuatan media tanah. Penentuan kandungan bakteri menggunakan metode tuang (Pour Plate Method) dengan menimbang sampel tanah sebanyak 1 gr dan memasukkan kedalam larutan trisalt sebanyak 9 ml sebagai pengenceran $10^{-1}$, kemudian dihomogenkan. Diambil $1 \mathrm{ml}$ larutan pada tabung $10^{-1}$ dengan mikropipet, masukkan kedalam tabung $10^{-2}$ homogenkan dengan vortex,begitu seterusnya untuk tingkat pengenceran selanjutnya $10^{-2}, 10^{-3}$,dan $10^{-4}$.Penanaman sampel kedalam media tanah dilakukan pertama yaitu sampel diambil dari setiap pengenceran sebanyak $0,1 \mathrm{ml}$ untuk ditaburkan ke media tanah, kemudian di ratakan dengan menggunakan spreader yang disterilkan dengan pembakaran, danInkubasi selama 24 - 48 jam dalam posisi plate terbalik.Perhitungan dilakukan dengan cara memberi tanda (grid) pada petri disc dan memberi tanda menggunakan spidol setiap koloni yang sudah dihitung.

Koloni yang tumbuh dihitung dengan jumlah koloni antara 30-300 cfu. Jumlah koloni (n) diantara kisaran tersebut kemudian diolah dengan rumus sebagai berikut:

$\mathbf{N}(\mathbf{c f u} / \mu \mathrm{l})=\mathbf{n}(\mathbf{c f u}) / \mathbf{5 0}(\boldsymbol{\mu l}) \times 10^{\mathrm{x}}$ atau,

$\mathbf{N}(\mathbf{c f u} / \mathrm{ml})=\mathbf{n}(\mathbf{c f u}) / \mathbf{5 0}(\mu \mathrm{l}) \times \mathbf{1 0}^{\mathrm{x}} \times 1000$

keterangan: jika volume yang diinokulasikan $50 \mu \mathrm{l}, \mathrm{n}=$ jumlah koloni bakteri dalam plate agar, $10^{\mathrm{x}}=$ seri pengenceran

\section{Analisis Bahan Organik Tanah}

Metode yang digunakan untuk mengukur bahan organik tanah atau sedimen yaitu menggunakan metode Gavimetri (Dirjen Perikanan Budidaya Air Payau, 1994).Teknik preparasi untuk bahan organik tanah pertama Mengambil sedimen basah atau lumpur.Mengeringkan dalam oven dengan suhu hangat $60^{\circ} \mathrm{C}$ selama 24 jam atau lebih hingga kering dan dapat digerus, dan menggerus bongkahan sedimen yang kering dengan "porcelain grinder" hingga halus kemudian memasukkan lagi ke oven selama semalam untuk meyakinkan bahan dalam bentuk kering mutlak.

Rumus yang digunakan untuk menghitung bahan organik total adalah sebagai berikut:

$$
\text { Bahan Urganik }=\frac{(w t-c)-(w c-c)}{w \tau-c} \times 100 \%
$$

Keterangan:

wt $=$ berat total (crucrible + sampel) sebelum dibakar

$\mathrm{wc}=$ berat total (crucrible + sampel) setelah dibakar

\section{Uji Statistik}

c = berat "crucible" kosong

Setelah memperoleh data, selanjutnya dilakukan uji stastistik regresi. Analisis regresi adalah suatu cara atau teknik untuk mencari hubungan antara variabel satu dengan variabel lain yang dinyatakan dalam bentuk persamaan matematik dalam hubungan yang fungsional. Secara umum, dapat dinyatakan pula bahwa apabila ingin mengetahui pengaruh satu variabel X terhadap satu variabel Y maka digunakan analisis regresi sederhana, dan apabila mengetahui pengaruh dua variabel $\mathrm{X}$ atau lebih terhadap variabel Y digunakan analisis regresi ganda (multiple) (Raharjo, 2014). Regresi yang digunakan dalam penelitian ini adalah Uji statistik regresi linier sederhana untuk melihat hubungan antara kandungan bahan organik (X) dengan total bakteri (Y). Sedangkan regresi liner berganda (multiple) untuk melihat hubungan antara tekstur sedimen (sand, silt, clay) (X) dengan bahan organic(Y).Pengolahan data menggunakan program statistik SPSS 16.0.

Data utama yang diuji adalah bahan organik dan total bakteri yang diambil waktu pasang dan surut pada tiga stasiun, dalam hal ini untuk mengetahui perbedaan pengambilan sampel waktu pasang dan surut serta untuk mengetahui perbedaan sampel antara ketiga stasiun dilakukan dengan Uji Analysis of variance, ANOVA : Twofactor (two way anova) atau anova dua faktor, untuk suatu pengujian yang analisisnya didasarkan pada dua 
perlakuan dengan data berbentuk kontingen (Arifin, 2005). Pengolahan data menggunakan aplikasi Microsoft Exel 2010.

\section{HASIL DAN PEMBAHASAN}

\section{a. Gambaran Umum Lokasi Sampling}

Lokasi penelitian terletak pada Muara Sungai Wiso atau Kali Wiso yang merupakan wilayah yang berada di Kelurahan Ujung Batu, Kecamatan Kota Jepara. Pengambilan sampel yang dilakukan dalam penelitian ini yaitu pada stasiun satu terletak pada koordinat $06^{\circ} 35^{\prime} 10.8^{\prime \prime}$ LS dan $110^{\circ} 39^{\prime} 51.5^{\prime \prime}$ BT yang merupakan bagian awal aliran Muara Sungai Wiso. Stasiun dua terletak pada koordinat 06³5'03.9” LS dan 110³9'35.2” BT yang merupakan bagian tengah aliran Muara Sungai Wiso. Stasiun tiga terletak pada koordinat $06^{\circ} 35^{\prime} 00.1^{\prime}$ ' LS dan $110^{\circ} 39^{\prime} 22.3$ ” BT yang merupakan bagian akhir aliran muara Sungai Wiso yang sudah berbatasan langsung dengan laut.

Stasiun satu merupakan awal aliran Muara Sungai Wiso yang terletak diantara wilayah pemukiman, pasar, dan pusat pertokoan.Stasiun dua merupakan bagian tengah aliran muara yang perairannya digunakan sebagai tempat bersandar kapal para nelayan.Penggunaan lahan di sepanjang aliran muara pada stasiun dua ini ialah sebagai tempat pemukiman warga.Stasiun tiga merupakan bagian akhir aliran Muara Sungai Wiso yang sudah berbatasan langsung dengan laut.Disekitar stasiun tiga ini digunakan sebagai Tempat Pelelangan Ikan (TPI) Ujung Batu, Jepara.Kondisi di TPI Ujung Batu sangat kotor yang mana dipenuhi dengan sampah dan berbau tidak sedap.Disekitar stasiun tiga ini juga merupakan tempat Pelabuhan Jepara sehingga terjadi aktivitas nelayan penangkap ikan dan digunakan sebagai tempat bersandarnya kapal para nelayan.

\section{b. Hasil}

1. Bahan Organik Total

Tabel 1. Hasil Perhitungan Rata- rata Bahan Organik (\%) di Sedimen Muara Sungai Wiso Jepara

\begin{tabular}{lccc}
\hline $\begin{array}{c}\text { Waktu dan Tempat } \\
\text { pengambilan Sampel }\end{array}$ & $\begin{array}{c}\text { Ulangan I } \\
\text { (15 April 2016) }\end{array}$ & $\begin{array}{c}\text { Ulangan II } \\
\text { (18 April 2016) }\end{array}$ & Rata - rata Stasiun \\
\hline Surut & & & \\
Stasiun I & 9,54 & 7,59 & 8,57 \\
Stasiun II & 15,60 & 16,45 & 16,03 \\
Stasiun III & 9,16 & 9,09 & 9,13 \\
Pasang & & & 8 \\
Stasiun I & 8,87 & 7,12 & 15,41 \\
Stasiun II & 16,57 & 14,24 & 9,76 \\
Stasiun III & 9,33 & 10,18 &
\end{tabular}

Sumber: Hasil Penelitian di Laboratorium Fisika Kimia Lingkungan BBPBAP Jepara (2016)

Diagram hasil perhitungan rata - rata bahan organik total pada sedimen di stasiun I, Stasiun II dan Stasiun II seperti tersaji pada Gambar 1.

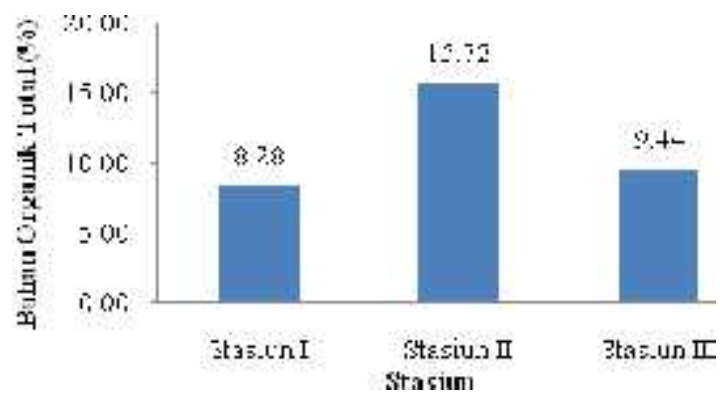

Gambar 1. Diagram Batang Rata-rata Bahan Organik pada Sedimen di Lokasi Penelitian

Berdasarkan hasil analisa data diperoleh $P=0,007$, nilai probabilitas tersebut lebih kecil dari 0,05 maka $\mathrm{H}_{0}$ di tolak dan $\mathrm{H}_{1}$ diterima ini berarti terdapat perbedaaan antara stasiun satu, stasiun dua dan stasiun tiga yang nyata. Diagram hasil perhitungan rata-rata bahan organik total di sedimen dasar muara sungai Wiso, Jepara seperti tersaji pada Gambar 2. 


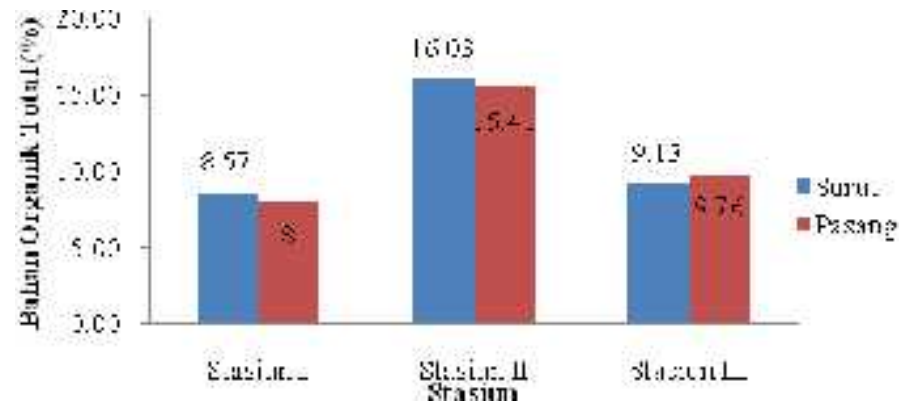

Gambar 2.Diagram Batang Rata-rata Bahan Organik di Sedimen pada saat Surut dan Pasang di Muara Sungai Wiso, Jepara

Berdasarkan hasil pengamatan dapat dilihat pada Gambar 2.Hasil analisis nilai probabilitas diperoleh $P=0,693$, nilai probabilitas tersebut lebih besar dibandingkan 0,05 maka $\mathrm{H}_{0}$ diterima dan $\mathrm{H}_{1}$ ditolak ini berarti tidak terdapat perbedaan nyata antara pasang dan surut. Dari hasil pengamatan menunjukkan rata - rata bahan organik tertinggi pada stasiun dua $15,72 \%$. Nilai tersebut dapat dikatakan bahwa kandungan bahan organik tergolong sedang karena masih dalam kisaran 7 - 17 \% (Foth, 1979).Menurut Achmad (2004), bahan organik merupakan sumber makanan bagi mikroorganisme di dalam tanah. Melalui reaksi-reaksi kimia yang terjadi seperti reaksi pertukaran kation akan dapat menentukan sifat kimia tanah. Diantara komponen-komponen aktif secara biologis dari bahan organik tanah adalah, polisakarida, gula-gula amino, nukliosida, dan belerang organik amino, nukleosida dan belerang organik serta senyawa-senyawa fosfat.Sebagian besar dari bahan organik di dalam tanah terdiri dari bahan-bahan yang tidak larut dalam air dan relatif tahan terhadap penguraian.Bahan ini disebut humus.Humus disusun oleh fraksi dasar yang disebut asam-asam humat dan fulvat dan sebuah fraksi tidak larut disebut humin.

2. Total Bakteri

Tabel 2. Hasil Perhitungan Rata- rata Total Bakteri (CFU/ml) di Sedimen Muara Sungai Wiso, Jepara

\begin{tabular}{lccc}
\hline $\begin{array}{c}\text { Waktu dan Tempat } \\
\text { pengambilan } \\
\text { Sampel }\end{array}$ & $\begin{array}{c}\text { Ulangan I } \\
(\mathbf{1 5} \text { April 2016) }\end{array}$ & $\begin{array}{c}\text { Ulangan II } \\
\mathbf{( 1 8} \text { April 2016) }\end{array}$ & $\begin{array}{c}\text { Rata - rata } \\
\text { Stasiun }\end{array}$ \\
\hline Surut & $6,8 \times 10^{6}$ & $4,0 \times 10^{6}$ & $5,4 \times 10^{6}$ \\
Stasiun I & $1,2 \times 10^{7}$ & $2,8 \times 10^{6}$ & $7,4 \times 10^{6}$ \\
Stasiun II & $5,2 \times 10^{5}$ & $4,1 \times 10^{5}$ & $4,6 \times 10^{5}$ \\
Stasiun III & & & \\
Pasang & $3,3 \times 10^{5}$ & $2,6 \times 10^{6}$ & $1,4 \times 10^{6}$ \\
Stasiun I & $2,6 \times 10^{6}$ & $3,0 \times 10^{6}$ & $2,8 \times 10^{6}$ \\
Stasiun II & $6,6 \times 10^{6}$ & $8,4 \times 10^{5}$ & $3,7 \times 10^{6}$ \\
Stasiun III &
\end{tabular}

Sumber:Hasil Penelitian di Laboratorium Manajemen Kesehatan Hewan Air (MKHA) BBPBAP Jepara (2016)

Diagram hasil perhitungan rata - rata total bakteri pada sedimen di stasiun I, Stasiun II dan Stasiun II seperti tersaji pada Gambar 3.

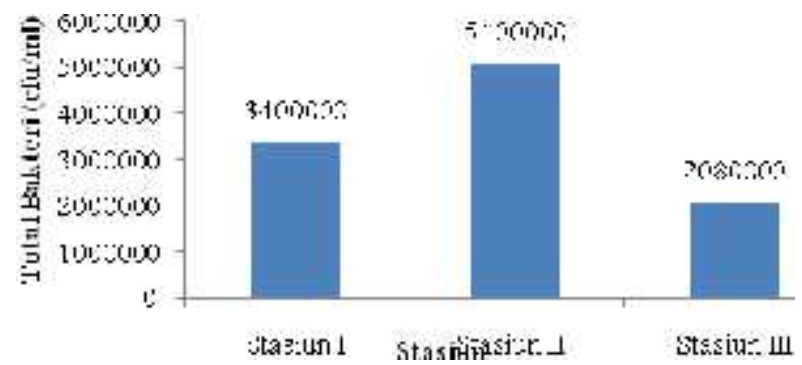

Gambar 3.Diagram Batang Rata-rata Total Bakteri pada Sedimen di di Lokasi Penelitian

Berdasarkan hasil pengamatan dapat dilihat pada Gambar 3. Hasil analisa data diperoleh $P=0,675$, nilai probabilitas tersebut lebih besar dari 0,05 maka $\mathrm{H}_{0}$ di terima dan tolak $\mathrm{H}_{1}$ ini berarti tidak ada perbedaaan antara stasiun satu, stasiun dua dan stasiun tiga.Perbandingan hasil total bakteri di sedimen berdasarkan pengambilan sampel pada saat air surut dan air pasang seperti tersaji pada Gambar 4. 


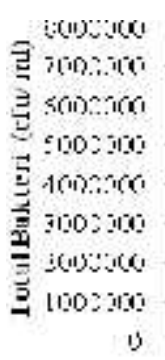

b)

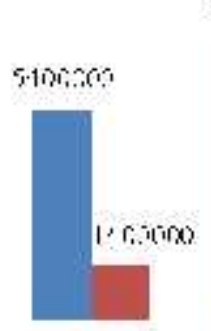

St:.'iu:」

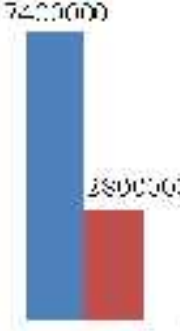

t.a silktyiu: 11

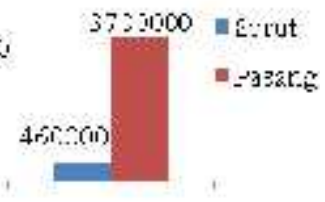

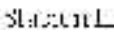

Gambar 4. Diagram Batang Rata-rata Total Bakteri di Sedimen pada saat Surut dan Pasang di Muara Sungai Wiso, Jepara

Berdasarkan hasil analisis nilai probabilitas diperoleh $P=0,552$, nilai probabilitas tersebut lebih besar dibandingkan 0,05 maka $\mathrm{H}_{0}$ diterima dan $\mathrm{H}_{1}$ ditolak ini berarti tidak terdapat perbedaan nyata antara pasang dan surut. Dari hasil yang didapat rata - rata total bakteri tertinggi terlihat pada stasiun dua yaitu rata - ratanya sebesar 5.100.000 cfu/ml. Diduga hal ini disebabkan karena pada stasiun dua banyak terdapat rumah penduduk dan aktivitas kapal - kapal yang bersandar pada badan sungai yang membuang limbahnya ke badan sungai. Sehingga mengakibatkan tingginya populasi total bakteri di sedimen pada area tersebut. Hal ini kemungkinan dipicu karena pertumbuhan bakteri tergantung dari bahan - bahan organik maupun anorganik sebagai sumber energinya, dan terurama berhubungan dengan dekomposisi, zat - zat tepung dan bahan - bahan nitrogen lainnya serta lemak sebagai bahan makanannya (Sutedjo, 1991).Kapal tangkap ikan yang banyak bersandar di sekitar aliran perairan muara pada stasiun dua ini mengakibatkan banyaknya limbah minyak (bahan bakar kapal) di perairan muara sungai wiso Jepara.Menurut Cooper et al. (1990) dalam Suyasa (2011), pada lingkungan yang telah lama tercemar limbah minyak atau lemak serta kolam pengolahan limbah minyak atau lemak dimungkinkan terdapat bakteri pendegradasi minyak atau lemak tersebut secara alamiah.Selain itu, lahan ini disekitar muara pada stasiun dua juga dijadikan kawasan pemukiman bagi warga setempat yang menyebabkan aliran air terkontaminasi limbah domestik dari kegiatan rumah tangga. Hal ini mengakibatkan total bakteri pada stasiun dua lebih banyak dibandingkan total bakteri pada stasiun lainnya. Menurut Gaudy (1980), pada limbah domestik yang berasal dari kegiatan rumah tangga pada umumnya banyak ditemukan mikroorganisme seperti golongan bakteri, jamur, dan virus.

\section{Tekstur Sedimen dan Kandungan Bahan Organik Sedimen}

Adanya perbedaan (tinggi rendahnya) total bakteri di masing - masing stasiun pada saat pasang maupun pada saat surut diduga karena adanya perbedaan kandungan bahan organik yang ada di tekstur sedimen lokasi penelitian. Hasil pengukuran tekstur sedimen dan bahan organik sedimen lebih lanjut tersaji pada tabel berikut: Tabel 3. Hasil Pengukuran Tekstur Sedimen dan Kandungan Bahan Organik di lokasi penelitian

\begin{tabular}{lcccc}
\hline $\begin{array}{c}\text { Waktu dan } \\
\text { Lokasi } \\
\begin{array}{c}\text { Pengambilan } \\
\text { Sampel }\end{array}\end{array}$ & $\begin{array}{c}\text { Berat Fraksi Pasir } \\
(\mathbf{\%})\end{array}$ & $\begin{array}{c}\text { Berat Fraksi } \\
\text { Debu } \mathbf{( \% )}\end{array}$ & $\begin{array}{c}\text { Berat Fraksi Liat } \\
\mathbf{( \% )}\end{array}$ & $\begin{array}{c}\text { Rata - rata Bahan } \\
\text { Organik }(\%)\end{array}$ \\
\hline Surut & & & & \\
Stasiun I & 5,7 & 3 & 91,3 & 8,57 \\
Stasiun II & 5,6 & 58 & 36,4 & 16,03 \\
Stasiun III & 19,2 & 20 & 60,8 & 9,13 \\
Pasang & 5,3 & 3 & 91,7 & 8 \\
Stasiun I & 7,1 & 56 & 36,9 & 15,41 \\
Stasiun II & 29,5 & 15 & 55,5 & 9,76 \\
Stasiun III & & & & \\
\hline
\end{tabular}

Sumber:Hasil Penelitian di Laboratorium Pengelolaan Sumberdaya Ikan dan Lingkungan UniversitasDiponegoro (2016)

Hasil Analisa Regresi Linier Berganda Hubungan Tekstur Sedimen dengan Kandungan Bahan Organik Sedimen dapat dilihat pada tabel berikut:

Model Summary ${ }^{b}$

\begin{tabular}{|c|c|c|c|c|c|c|c|c|c|}
\hline \multirow{2}{*}{$\begin{array}{l}\text { Mo } \\
\text { del }\end{array}$} & \multirow[t]{2}{*}{$\mathrm{R}$} & \multirow{2}{*}{$\begin{array}{l}\mathrm{R} \\
\text { Square }\end{array}$} & \multirow{2}{*}{$\begin{array}{l}\text { Adjusted } \\
\text { R Square }\end{array}$} & \multirow{2}{*}{$\begin{array}{l}\text { Std. Error } \\
\text { of the } \\
\text { Estimate }\end{array}$} & \multicolumn{5}{|l|}{ Change Statistics } \\
\hline & & & & & R Square Change & F Change & df1 & df2 & $\begin{array}{l}\text { Sig. F } \\
\text { Change }\end{array}$ \\
\hline 1 & $1.000^{\mathrm{a}}$ & 1.000 & 1.000 & .00515 & 1.000 & $8.110 \mathrm{E} 5$ & 3 & 2 & .000 \\
\hline
\end{tabular}

Predictors: (Constant), clay, sand, silt 
Correlations

\begin{tabular}{|l|l|r|r|r|r|}
\hline & & \multicolumn{1}{|c|}{ BO } & \multicolumn{1}{c|}{ sand } & \multicolumn{1}{c|}{ silt } & \multicolumn{1}{c|}{ clay } \\
\hline \multirow{3}{*}{ BO } & Pearson Correlation & 1 & -.296 & $.985^{* *}$ & $1.000^{* *}$ \\
\cline { 2 - 6 } & Sig. (2-tailed) & & .569 & .000 & .000 \\
\cline { 2 - 6 } & $\mathrm{N}$ & 6 & 6 & 6 & 6 \\
\hline
\end{tabular}

**. Correlation is significant at the 0.01 level (2-tailed).

Hasil analisa regresi linier berganda menunjukan adanya hubungan antara tekstur sedimen dengan bahan organik sedimen dengan nilai $r=1$ yang artinya kedua variabel memiliki hubungan yang sempurna. Menurut Maslukah (2006), kandungan bahan organik erat kaitannya dengan jenis sedimen. Jenis sedimen perairan yang berbeda akan mempunyai kandungan bahan organik yang berbeda pula. Bahan organik berkaitan erat dengan unsur hara.Bahan organik tinggi, berarti unsur hara tinggi juga.

Struktur sedimen pada Muara Sungai Wiso Jepara terdiri atas 3 jenis yaitu pasir, lumpur, dan liat.Hal ini berkaitan dengan kandungan bahan organik sedimen yang ada di dasar perairan. Berdasarkan hasil dari pengukuran menggunakan segitiga tekstur tanah, stasiun satu dan tiga memiliki karakteristik sedimen yang sama yaitu tekstur liat, dan stasiun dua memiliki tekstur lempung liat berdebu. Berdasarkan hasil analisa korelasi Pearson (Tabel. 6) hubungan fraksi liat dengan kandungan bahan organik memiliki korelasi sempurna yaitu $r=$ 1, hal ini menunjukkan adanya fraksi liat yang mendominasi di muara Sungai Wiso Jepara. Menurut Hanafiah (2005), dominasi fraksi liat akan menyebabkan terbentuknya banyak pori - pori mikro, sehingga permukaan sentuhnya sangat luas, sehingga daya pegang terhadap air sangat kuat. Kondisi ini menyebabkan air yang masuk ke pori - pori segera terperangkap dan udara sulit masuk. Hasil pada penelitian menunjukkan pada stasiun dua semakin halus tekstur sedimen makan semakin tinggi kandungan bahan organiknya.Hal ini di perkuat menurut Rifardi (2012), dilihat dari kemampuan absorpsi sedimen bahwa pada dasar perairan mempunyai kemampuan absorpsi terhadap bahan asing (pencemar) yang masuk dan kemampuan absorpsi ini tergantung pada ukuran butir sedimen.Semakin halus butiran sedimen dasar perairan semakin kuat daya absorpsinya dan sebaliknya.Walaupun bahan organik larut dalam air, sedimen juga mempunyai kemampuan menyerapnya.

\section{Hubungan antara Kandungan Bahan Organik dengan Kepadatan Total Bakteri}

Hasil Analisa Regresi Linier Sederhana Kandungan Bahan Organik dengan Kepadatan Total Bakteri sedimen dapat dilihat pada tabel berikut:

Model Summary ${ }^{\mathbf{b}}$

\begin{tabular}{|l|r|r|r|r|}
\hline Model & \multicolumn{1}{|c|}{$\mathrm{R}$} & R Square & Adjusted R Square & Std. Error of the Estimate \\
\hline 1 & $.511^{\mathrm{a}}$ & .262 & .077 & $2.46816 \mathrm{E} 6$ \\
\hline
\end{tabular}

a. Predictors: (Constant), BO

b. Dependent Variable: TB

\begin{tabular}{|l|l|r|r|r|r|r|}
\hline \multicolumn{2}{|l|}{ Model } & Sum of Squares & df & Mean Square & F & Sig. \\
\hline \multirow{3}{*}{1} & Regression & $8.630 \mathrm{E} 12$ & 1 & $8.630 \mathrm{E} 12$ & 1.417 & $.300^{\mathrm{a}}$ \\
\cline { 2 - 8 } & Residual & $2.437 \mathrm{E} 13$ & 4 & $6.092 \mathrm{E} 12$ & & \\
\cline { 2 - 8 } & Total & $3.300 \mathrm{E} 13$ & 5 & & & \\
\hline
\end{tabular}

a. Predictors: (Constant), BO

b. Dependent Variable: TB

Berdasarkan hasil analisis menunjukkan korelasi tidak terlalu kuat antara total bakteri pada sedimen dan bahan organik total pada sedimen, dikarenakan nilai $r$ cukup yaitu $0,511\left(R^{2}=0,262\right)$. Menurut Sugiyono (2007) bahwa nilai $0,4<\mathrm{r} \leq 0,69$ maka memiliki korelasi cukup. Nilai determinasi koefisien penentu $(\mathrm{KP})$ sebesar $\left(\mathrm{R}^{2}=\right.$ 0,262) yang artinya 26,2 \% bahan organik mempengaruhi total bakteri dan sisanya 73,8 \% di pengaruhi oleh variabel lain. Namun berdasarkan hasil analisis ANOVA hubungan antara dua variabel tersebut tidak signifikan (P> 0,05).Menurut Hanafiah (2005), bahan organik tanah biasanya menyusun sekitar $5 \%$ bobot total tanah meskipun hanya sedikit tetapi memegang peran penting dalam menentukan kesuburan tanah, baik secara fisik, kimiawi maupun secara biologis tanah. Sebagai komponen tanah yang berfungsi sebagai media tumbuh, maka bahan organik juga berpengaruh secara langsung terhadap perkembangan dan pertumbuhan tanaman dan mikrobia tanah, yaitu sebagai sumber energi, hormon, vitamin dan senyawa perangsang tumbuh lainnya.

Konsentrasi bahan organik dan kepadatan total bakteri di sedimen muara Sungai Wiso keberadaannya tentunyadi dukung parameter lainnya seperti fisika maupun kimia. Menurut Waluyo (2005), mikroorganisme heterotrofik mendapatkan bahan organik sebagai makanan untuk aktivitasnya. Dalam kultur murni bakteri terdapat korelasi yang positif antara jumlah dan biomassa sel - sel aktif dan konsumsi substrat. Dalam kultur campuran populasi mikroba akuatik, hubungan tersebut tidak selalu benar disebabkan tidak semua keberadaan bakteri memerlukan nutrien yang sama. Tergantung dari kualitas dan konsentrasi bahan - bahan organik yang dipengaruhi oleh faktor lingkungan seperti temperatur air, reaksi, kandungan garam dan tekanan hidrostatik maka kapasitas konsumsi mikroorganisme menjadi berbeda-beda.

Bahan organik di sedimen muara Sungai Wiso, Jepara memiliki kriteria sedang yaitu berkisar antara 7-17\% (Foth, 1979). Diikuti dengan pertumbuhan total bakteri yang relatif sama di ketiga stasiun tersebut. Berdasarkan 
hasil dari ANOVA antara kedua variabel adalah $\mathrm{P}($ sig $)=0,3$ atau $\mathrm{P}($ sig $)>0,05$, yang artinya $\mathrm{H}_{0}$ ditolak yaitu tidak terdapat hubungan nyata antara kandungan bahan organik dengan total bakteri. Hal ini menunjukkan bahan organik tidak mempunyai pola hubungan yang positif dengan total bakteri. Walaupun nilai keeratan antara bahan organik dengan total bakteri di sedimen dalam penelitian ini cukup erat $(\mathrm{r}=0,511)$.

\section{Parameter Kualitas Lingkungan Pendukung}

Tabel 4. Hasil Pengukuran Parameter Kualitas Lingkungan di Muara Sungai Wiso Jepara

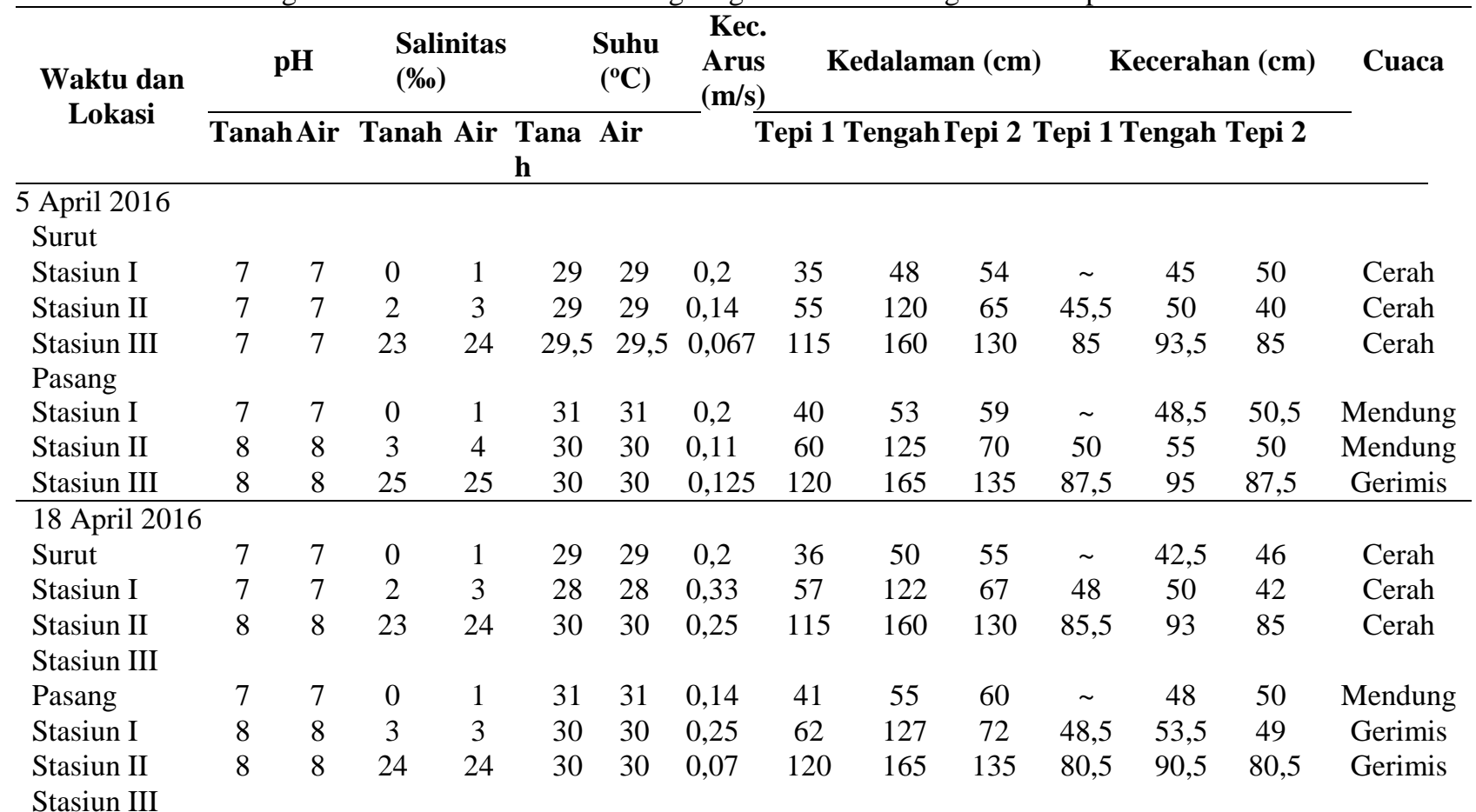

Sumber: Hasil Penelitian (2016)

Parameter fisika kimia juga mungkin sangat mempengaruhi kehidupan pertumbuhan bakteri. Pada penelitian diperoleh hasil salinitas yang tinggi pada staiun tiga yaitu berkisar $23-25 \%$ dimana staiun ini berbatasan langsung dengan laut. Menurut Oktaviana (2014), terjadi hubungan negatif antara salinitas dan total bakteri. Semakin tinggi salinitas maka semakin berkurang total bakteri.Hasil pengukuran pada penelitian di stasiun tiga didapatkan hasil (Tabel 4) salinitas lebih tinggi dari pada stasiun yang lain dan hasil (Gambar 3) total bakteri di stasiun tiga lebih rendah dari pada staiun yang lain.

Dari hasil penelitian $\mathrm{pH}$ air pada saat pasang dan surut didapat kisaran sebesar 7 - 8, nilai tersebut sama halnya dengan nilai $\mathrm{pH}$ tanah. Menurut Askari (2010), $\mathrm{pH}$ mempengaruhi tidak saja aktivitas mikroorganisme tetapi juga keragaman spesiesnya. Aktivitas enzim mikroba tergantung kepada ion $\mathrm{H}^{+}$, oleh karena itu $\mathrm{pH}$ tanah mempengaruhinya. Pada umumnya kebanyakan mikroorganisme tumbuh optimum pada kisaran pH $6-$ 8.Meskipun demikian mikroorganisme juga masih dapat tumbuh dengan baik diluar kisaran pH tersebut.

Kedalaman pada suatu perairan akan mempengaruhi berbagai faktor lingkungan seperti suhu dan kecerahan yang tentunya akan mempengaruhi penyebaran dari bakteri sedimen. Berdasarkan penelitian kedalaman perairan tepi 1 (selatan) dan tepi 2 (utara) lebih dangkal dibandingkan dengan bagian tengah.Kecepatan arus dapat membawa partikel - pertikel terlarut dari daerah hulu dan kemudian mengendap di hilir sungai. Menurut Waluyo (2005), lumpur yang berisi bakteri dan bahan - bahan organik yang telah terurai dapat didapatkan dari kedalaman lumpur yang hanya beberapa centimeter. Pada kedalaman 1 meter jumlah bakteri hanya sedikit dibandingkan pada permukaan.

Parameter fisika kimia diduga memiliki pengaruh terhadap fluktuasi bahan organik. Menurut Hanafiah (2005), temperatur mempengaruhi laju dekomposisi bahan organik sebagai dampak pengaruhnya terhadap jenis mikrobia yang dominan. Umumnya proses dekomposisi maksimum pada temperatur $30-35{ }^{\circ} \mathrm{C}$ atau hingga 45 ${ }^{\circ} \mathrm{C}$. Pada temperatur dibawah $30{ }^{\circ} \mathrm{C}$ atau di atas $45^{\circ} \mathrm{C}$ proses dekomposisi terhambat. Temperatur pada penelitian berkisar $28^{\circ} \mathrm{C}-31{ }^{\circ} \mathrm{C}$.Menurut Hayes (2000), kelimpahan bakteri sering terjadi pada lingkungan perairan kaya bahan organik dengan suhu lebih dari $10{ }^{\circ} \mathrm{C}$.

Hasil analisajika dilihat berdasarkan pengambilan pasang dan surut, hasil analisa bahan organik populasinya tidak berbeda nyata dengan nilai $P=0,693$ dan hasil analisa total bakteri populasinya juga tidak berbeda nyata dengan nilai $P=0,552$, nilai probabilitas tersebut lebih besar dari 0,05 maka $\mathrm{H}_{0}$ diterima dan $\mathrm{H}_{1}$ ditolak ini berarti tidak terdapat perbedaan nyata antara pasang dan surut.Menurut Wibisono (2010), diwilayah sekitar estuaria (muara sungai) yang cukup lebar dan panjang, kondisi pasang surut sedikit banyak juga mendapat pengaruh aliran sungai tersebut. Walaupun energi pasang dari laut akan menjadi berkurang sebanding

${ }^{\circledR}$ Copyright by Management of Aquatic Resources (MAQUARES) 
dengan berkurangnya kedalaman, namun begitu memasuki ertuari air sungai didesak ke atas sehingga alirannya relatif terhenti pada saat puncak pasang tertinggi selama beberapa saat. Hal ini berarti permukaan air sungai sama tinggi dengan permukaan air laut dimana kecepatan aliran kedua belah pihak menjadi nol. Sehingga tidak terdapat perbedaan nyata atau relatif sama antara pengambilan sampel waktu pasang dan surut.

\section{KESIMPULAN}

Berdasarkan penelitian yang dilakukan dapat diambil kesimpulan sebagai berikut:

1. Total bakteri di sedimen dasar Muara Sungai Wiso Jepara berkisar antara 3,3 x $10^{5} \mathrm{cfu} / \mathrm{ml}$ hingga $1,2 \times 10^{7}$ $\mathrm{cfu} / \mathrm{ml}$;

2. Kandungan bahan organik di sedimen Muara Sungai Wiso jepara berkisar antara $7,12 \%$ hingga $16,57 \%$ yang artinya bahan organik termasuk dalam kriteria sedang yaitu berkisar antara $7 \%$ - $17 \%$; dan

3. Bahan organik tidak mempunyai pola hubungan positif yang nyata dengan total bakteri. Namun kenyataan yang diperoleh dari keeratan antara bahan organik dengan total bakteri sedimen dalam penelitian ini memiliki tingkat keeratan sebesar $\mathrm{r}=0,511$ yang artinya keeratan kedua variabel cukup erat.

\section{UCAPAN TERIMA KASIH}

Ucapan terima kasih ditujukan kepada, Ir. Siti Rudiyanti, M.Si; Churun Ain, S.Pi, M.Si; Dr.Ir. Bambang Sulardiono, M.Si; Dr. Ir. Pujiono Wahyu Purnomo, M.S selakutim penguji dan panitia yang telah memberikan masukan serta arahan kepada penulis. Kepadadrh. Ch. Retna Handayani, M.Si; Sri Murti Astuti, S.P; Ir. M Syahrul Latief, M.Si; Ibu Zariah dan Ibu Purwanahpihak Laboratorium Balai Besar Pengembangan Budidaya Air Payau (BBPBAP) Jepara yang telah memberikan izin, bimbingan, serta arahan kepada penulis dalam pelaksanaan analisa di laboratorium.

\section{DAFTAR PUSTAKA}

Achmad, R. 2004. Kimia Lingkungan. Penerbit ANDI yogyakarta, Universitas Negeri Jakarta, Jakarta.

Arifin, J. 2005. Aplikasi Exel dalam Statistik dan Riset Terapan.PT Elex Media komputindo Kelompok Gramedia. Jakarta.

Askari, W. 2010.Tanah Sebagai Habitat Mikroorganisme.http://wahyuaskari.wordpress.com/akademik/tanahsebagai-habitat-mikroorganisme/ (18 April 2016).

Dirjen Perikanan Budidaya Air Payau. 1994. Pedoman Analisis Kualitas Air dan Tanah Sedimen, Jepara.

Foth, H. D. 1979. Dasar - Dasar Ilmu Tanah. Erlangga, Jakarta.

Gaudy, A. F. And E. T Gaudy. 1980. Microbiology for Environmental Scientis and Engineer. McGraw Hill. New York. 736 pages.

Ghufran, M., Kordi, H.K, dan Tancung A.B. 2007.Pengelolaan Kualitas Air dalam Budidaya Perairan.Rineka cipta. Jakarta.

Hanafiah, K. A. 2005. Dasar- dasar Ilmu Tanah.PT Rajagrafindo Persada. Jakarta.

Hayes, J. 2000. Aeromonas Hydrophilla. MB592-Desease of fish.Oregon State University.http://hmsc.oregonstate.edu/classes/MB492/hydrophilahayes(24 Juni 2016). Hal 143.

Kunarso, D. H dan Titiek, I. A. 2012.Kajian Bakteri Heterotrof di Perairan Laut Lamalera. Ilmu Kelautan Undip. 17 (2) : 63-67.

Maslukah, L. 2006. Konsentrasi Logam Berat Pb, Cd, Zn dan Pola Sebarannya Di Muara Banjir Kanal Semarang.[Tesis].Fakultas Perikanan dan Ilmu Kelautan, Institut Pertanian Bogor, Bogor. .

Oktaviana, T. K. 2014. Total Bakteri dan C/N dalam Sedimen Sungai Sekembu Jepara dalam Kaitannya dengan Pencemaran.[Skripsi].Fakultas Perikanan dan Ilmu Kelautan, Universitas Diponegoro, Semarang.

Raharjo, S. 2014. Cara Melakukan Analisis Regresi Multiples dengan SPSS.http://www.spssindonesia.com/2014/02/analisis-regresi-multipes-dengan-spss.html(12 Agustus 2016).

Rifardi.2012. Ekologi Sedimen Laut Modern.UR Press.Pekanbaru.

SNI-01-2339-1991 tentang Penentuan Angka Lempang Total.

Sugiyono.2007. Metode Penelitian Kuantitatif Kualitatif dan R \& D. Alfabeta, Bandung.330 hlm. 
Sujarweni, V. W. 2014. Metodologi Penelitian Lengkap, Praktis, dan Mudah dipahami. Cetakan I, Yogyakarta, Pustaka Baru press. $11 \mathrm{hlm}$.

Sutedjo, MM. 1991. Mikrobiologi Tanah. Rineka Cipta. Jakarta.

Suyasa, I. W. Budiarsa. 2011. Isolasi Bakteri Pendegradasi Minyak/lemak dari Beberapa Sedimen Perairan Tercemar dan Bak Penampungan Limbah. Jurnal FMIPA. Universitas Udayana, Bali 7 (1) : 1 - 6.

Waluyo, L. 2005. Mikrobiologi Lingkungan. UMM Press, Malang.

Wijoyono. 2009. Keanekaragaman bakteri serasah daun Avicennian marina yang Mengalami Dekomposisi pada Berbagai Tingkat Salinitas di Teluk Tapian Nauli. Universitas Sumatra Utara Medan.

Wulandari, D. 2011. Peran Bakteri bagi Kehidupan. http://destiwd.blogspot.com/2015/11/ peran-bakteri-dalamkehidupan.html(18 April 2016). 